\title{
Pengaruh Beta Saham, Likuiditas Saham, Atribut Audit, dan Tata Kelola Perusahaan Terhadap Biaya Modal Ekuitas
}

\author{
Olivia Meirina M. \\ Universitas Katolik Soegijapranata \\ oliviameirina@gmail.com \\ Sansaloni Butar Butar \\ Universitas Katolik Soegijapranata \\ sansaloni@unika.ac.id
}

\begin{abstract}
This study aims to examine the effect of stock beta, stock liquidity, KAP size, industry auditor specialization, board of commissioner independence, and audit committee expertise on cost of equity capital. Cost of equity capital was measured with Capital Assets Pricing Model $(C A P M)$. This research use secondary data and the data was collected using purposive sampling at company that is registeres at Indonesian Stock Exchange 2013-2016. Total of the sample in this research is 800 companies. The test equipment in this research using multiple regression test. The results showed that stock beta, KAP size, and independence of board of commissioner have a positive effect on cost of equity capital. Auditor industry specialization has negative effect on the cost of equity capital. Meanwhile stock liquidity and audit committee's expertise have no effect on cost of equity capital.
\end{abstract}

Keywords: beta stocks, stock liquidity, audit attributes, good corporate governance, cost of equity capital

\begin{abstract}
Abstrak
Penelitian ini bertujuan untuk menguji pengaruh beta saham, likuditas saham, ukuran KAP, spesialisasi industri auditor, independensi dewan komisaris, dan keahlian komite audit terhadap biaya modal ekuitas. Biaya modal ekuitas diukur menggunakan Capital Assets Pricing Model (CAPM). Penelitian ini menggunakan data sekunder dan pemilihan sampel menggunakan metode purposive sampling pada perusahaan yang terdaftar di Bursa Efek Indonesia periode 2013-2016. Sampel yang digunakan dalam penelitian ini sebanyak 800 perusahaan. Alat uji yang digunakan pada penelitian ini adalah uji regresi berganda. Hasil penelitian menunjukan bahwa beta saham, ukuran KAP, dan independensi dewan komisaris berpengaruh positif terhadap biaya modal ekuitas. Spesialisasi industri auditor berpengaruh negatif terhadap biaya modal ekuitas. Sedangkan likuiditas saham dan keahlian komite audit tidak berpengaruh terhadap biaya modal ekuitas.
\end{abstract}

Kata kunci: beta saham, likuiditas saham, atribut audit, good corporate governance, biaya modal ekuitas 


\section{PENDAHULUAN}

Persaingan antar perusahaan yang semakin ketat saat ini mendorong perusahaanperusahaan berlomba dalam meningkatkan kinerja perusahaan agar terus tumbuh dan berkembang. Dana yang dibutuhkan oleh perusahaan untuk meningkatkan kinerja dapat diperoleh dari investor yang menanamkan investasinya pada perusahaan tersebut. Namun, perusahaan perlu menunjukkan hasil kinerja yang baik supaya dapat menarik minat para investor untuk berinvestasi di perusahaannya (Suparno dan Kiswara, 2013).

Investor yang telah memutuskan untuk berinvestasi pada suatu perusahaan mengharapkan pengembalian atas investasi yang ditanamkannya pada perusahaan tersebut. Perusahaan sebagai pihak yang menggunakan dana mengeluarkan sejumlah biaya untuk memperoleh dana tersebut. Biaya-biaya ini disebut dengan biaya modal ekuitas (cost of equity). Biaya modal ekuitas merupakan biaya yang harus ditanggung oleh perusahaan yang memperoleh dana dengan menerbitkan saham.

Ningsih dan Ariani (2016) melaporkan bahwa rata-rata persentase biaya modal ekuitas dari 23 perusahaan LQ 45 pada tahun 2013 mengalami peningkatan sebesar 6,286\%, sedangkan pada tahun 2014 biaya modal ekuitas mengalami penurunan rata-rata sebesar $9,045 \%$. Salah satu faktor yang dapat mempengaruhi biaya modal ekuitas adalah risiko atau beta saham yang harus dihadapi oleh investor ketika akan berinvestasi. Hasil penelitian Dewi et al. (2017), Ashidiqi (2013), dan Fahdiansyah (2016) menunjukkan bahwa beta saham berpengaruh positif terhadap biaya modal ekuitas.

Jumlah saham yang diperdagangkan perusahaan untuk mendapatkan sumber modal dari para investor juga dapat mempengaruhi besarnya biaya modal ekuitas yang perlu dikeluarkan perusahaan. Hasil penelitian Efrina dan Faisal (2017), Fard (2017) dan Zorn (2007) menunjukkan likuiditas saham berpengaruh negatif terhadap biaya modal ekuitas.

Perubahan biaya modal ekuitas yang terjadi pada perusahaan juga dapat disebabkan oleh atribut audit. Audit memiliki peran penting untuk meyakinkan investor mengenai keandalan laporan keuangan yang disajikan oleh manajemen (Desiliani, 2014). Hasil-hasil penelitian sebelumnya menunjukkan hasil yang tidak konsisten. Bella (2017) menemukan bahwa ukuran KAP tidak berpengaruh terhadap biaya modal ekuitas tetapi spesialisasi industri auditor berpengaruh negatif terhadap biaya modal ekuitas. Yanesari (2012) menemukan bahwa ukuran KAP berpengaruh negatif terhadap biaya modal ekuitas.

Sebagian besar perusahaan lebih banyak bergantung pada sumber modal eksternal (Nasution, 2009). Ketergantungan perusahaan menyebabkan perusahaan perlu meyakinkan pihak-pihak penyandang dana eksternal bahwa dana yang masuk telah dikelola dengan tepat dan efisien, salah satunya dengan menerapkan sistem tata kelola perusahaan yang baik (good corporate governance). Berdasarkan hasil dari perception survey yang dilakukan oleh McKinsey (2000) lebih dari $80 \%$ investor bersedia membayar lebih untuk perusahaan yang memiliki tata kelola yang baik (well-governed). Hal ini berarti GCG (good corporate governance) menjadi salah satu pertimbangan investor dalam berinvestasi sehingga dapat berpengaruh terdapat biaya modal ekuitas.

Hasil penelitian Chairunnisa (2014) dan Rosita (2016) mengenai pengaruh good corporate governance terhadap cost of equity capital menunjukkan bahwa GCG yang terdiri dari dewan komisaris independen dan komite audit berpengaruh negatif terhadap cost of equity capital. Sari dan Vera (2014) menemukan bahwa ukuran komite audit berpengaruh negatif terhadap biaya modal ekuitas. Khemakhem dan Naciri (2015) menemukan keahlian 
komite audit berpengaruh negatif terhadap biaya modal ekuitas. Hasil-hasil penelitian tersebut menunjukkan bahwa komite audit yang dapat melaksanakan fungsi pengawasan secara efektif dapat menekan biaya modal ekuitas perusahaan. Hasil ini mencerminkan para investor menjadikan keahlian dan ukuran komite audit sebagai pertimbangan dalam pengambilan keputusan untuk berinvestasi karena dapat mencerminkan transparansi informasi dari perusahaan.

Faktor yang lain yang juga dapat mempengaruhi biaya modal ekuitas adalah kualitas laporan keuangan dan risiko saham. Winarto (2012) meneliti dan menemukan pengaruh manajemen laba terhadap biaya modal ekuitas pada perusahaan di BEI. Dewi et al. (2017), meneliti mengenai pengaruh beta saham terhadap biaya modal ekuitas dan menemukan bahwa beta saham berpengaruh positif terhadap biaya modal ekuitas. Penelitian ini bertujuan menguji kembali faktor-faktor yang mempengaruhi biaya modal ekuitas di BEI untuk menilai konsistensi determinan biaya modal ekuitas di pasar modal Indonesia.

\section{TINJAUAN LITERATUR DAN PERUMUSAN HIPOTESIS}

\section{Agency Theory}

Menurut teori keagenan (agency theory), hubungan-hubungan antara berbagai pihak di dalam perusahaan merupakan suatu bentuk kontrak antara principal dan agent. Dalam perusahaan modern, para pemegang saham dapat dipandang sebagai prinsipal dan manajer sebagai agent. Karena keterbatan waktu dan kemampuan, principal mendelegasikan wewenang pengambilan keputusan kepada manajer. Eisenhardt (1989) dalam Pujiningsih (2011) menyatakan bahwa teori keagenan menggunakan tiga asumsi sifat dasar manusia yaitu: (1) manusia pada umumnya mementingkan diri sendiri (2) manusia memiliki daya pikir terbatas (3) manusia selalu menghindari risiko. Berdasarkan asumsi tersebut pihak agen dan principal sama-sama berusaha untuk memaksimalkan kepentingan pribadinya masing-masing (Puteri, 2012).

Menurut teori keagenan, manajer (agen) memiliki informasi yang lebih lengkap tentang kinerja perusahaan dibandingkan pemegang saham (prinsipal) dan berpotensi menimbulkan konflik. Konflik yang disebabkan adanya perbedaan kepentingan antara pemilik (principal) dan pengelola (agent) dapat menimbulkan biaya sehingga harus dicegah. Salah satunya adalah dengan menerapkan berbagai mekanisme pengawasan yang dapat mencegah perilaku oportunistik manajer. Apabila perusahaan gagal membentuk perangkat untuk mengawasi manajer, maka kepercayaan investor terhadap kinerja perusahaan akan menurun dan mereka akan menuntut biaya modal yang lebih tinggi ketika membeli saham perusahaan.

\section{Biaya Modal Ekuitas (cost of equity)}

Cost of equity capital dapat diidentifikasi sebagai tingkat return minimum yang disyaratkan oleh penggunaan cost of equity (modal ekuitas) atas investasi (Tarjo, 2010). Biaya modal ekuitas (cost of equity) merupakan biaya yang dikeluarkan perusahaan untuk membiayai sumber pembiayaan. Cost of equity capital merupakan biaya yang dikeluarkan oleh perusahaan yang memperoleh dana dengan menjual saham biasa atau menggunakan laba yang ditahan untuk investasi (Imran, 2012). Menurut Lambert dalam Desliani (2014) menyatakan bahwa perusahaan dapat mengelola biaya modal ekuitas dengan mengendalikan kualitas informasi. Oleh karena itu, perusahaan mencari pengurangan dari biaya modal ekuitas untuk dapat meningkatkan nilai perusahaan (Desiliani, 2014). 
Menurut Utami dalam Kirana (2013) biaya modal ekuitas dapat diukur dengan menggunakan :

a. Model penilaian partumbuhan konstant (Constant growth valuation model)

Model ini mengukur dengan menganggap nilai saham sama dengan present value dari semua dividen yang akan diterima di masa yang akan datang (diasumsikan pada tingkat pertumbuhan konstan) dalam waktu yang tidak terbatas.

b. Capital Asset Pricing Model (CAPM);

Model ini mengukur biaya modal ekuitas dengan tingkat return yang diharapkan oleh investor sebagai kompensasi atas risiko yang tidak dapat dideversifikasi yang diukur dengan beta.

c. Model Ohlson.

Model Ohlson ini digunakan untuk menghitung estimasi nilai perusahaan dengan mendasarkan pada nilai buku ekuitas ditambah dengan nilai tunai dari laba abnormal.

Biaya modal ekuitas cukup penting karena : (1) digunakan untuk memaksimalkan nilai perusahaan maka seorang manajer harus meminimalkan biaya dari semua masukan, termasuk biaya modal (2) manajer keuangan memerlukan estimasi dari biaya modal agar dapat mengambil keputusan yang tepat di bidang penganggaran barang modal, (3) untuk menentukan berbagai macam keputusan yang diambil oleh manajer keuangan (Imran, 2012).

\section{Kualitas Audit}

Menurut Purwono dalam Mukminim (2010) audit merupakan sebuah proses sistematis auditor yang memiliki kompetensi, independensi, dan objektivitas mengenai perolehan dan penilaian bukti yang dikumpulkan dan dikuantifikasikan terkait dengan berkenaan dengan pernyataan dan kriteria yang telah ditetapkan kemudian haislnya dikomunikasikan kepada pihak-pihak pemangku kepentingan. Audit yang dilakukan terhadap laporan keuangan bertujuan untuk menambah kredibilitas laporan keuangan.

Kualitas laporan keuangan dapat dipengaruhi oleh kualitas auditor yang melakukan penugasan audit. Menurut Butar Butar (2014), pemilihan auditor yang akan mengaudit laporan keuangan memberi sinyal kepada pengguna tentang kualitas laporan keuangan. Auditor big Four dianggap memiliki kemampuan audit yang lebih baik baik daripada non-Big Four. Menurut Palmrose (1988), kualitas audit tercermin dari probabilitas laporan keuangan bebas salah saji material.

\section{Spesialisasi Industri Auditor}

Spesialisasi industri auditor menyiratkan pengetahuan luas yang dimiliki auditor tentang bisnis yang dijalankan klien, praktek akuntansi perusahaan, dan potensi penyalahgunaan praktek akuntansi (Suparno, 2013). Auditor dengan spesialisasi industri dipandang sebagai auditor yang memberikan audit dengan kualitas tinggi karena memiliki pengetahuan tentang industri tertentu dan juga dapat mengaudit lebih efisien melalui spesialisasinya (Kirana, 2013). Auditor spesialis diyakini mampu mendeteksi kesalahankesalahan secara lebih baik, meningkatkan efisiensi dan meningkatkan penilaian tentang kejujuran laporan keuangan. Selain itu, Pengguna laporan keuangan lebih mempercayai laporan keuangan yang diaudit oleh auditor yang memiliki spesialisasi industri daripada yang diaudit oleh auditor tanpa spesialisasi industri.

Spesialisasi industri KAP dilihat melalui frekuensi KAP dalam melakukan audit pada perusahaan industri yang sejenis menurut pengelompokan industri oleh BEI. Semakin sering KAP melakukan pemeriksaan terhadap perusahaan sejenis, maka KAP tersebut akan spesialis dalam kelompok perusahaan tersebut. Spesialisasi industri mengacu pada pengetahuan 
industri spesifik dan keahlian seorang auditor yang diperoleh dari audit yang luas dalam industri siapapun (Desiliani, 2014).

Ada dua cara yang dapat digunakan untuk mengidentifikasi auditor spesialisasi industri, yaitu : 1). Market share dalam industri. Pendekatan ini dapat mengukur spesialisasi industri auditor dengan cara menghitung berdasarkan presentase jumlah klien yang diaudit dalam suatu industri. 2). Market share dalam KAP. Pendekatan ini sering disebut portofolio share, yang meggambarkan distribusi pendapatan KAP berdasarkan industri.

\section{Beta Saham}

Beta saham merupakan suatu pengukur volalitas (volality) return suatu sekuritas atau portofolio terhadap return pasar (Dewi et al. 2017). Beta sekuritas ke-i mengukur volalitas return sekuritas ke-i dengan return pasar. Beta portofolio mengukur volalitas return portofolio dengan return pasar. Dengan demikian beta merupakan pengukur risiko sistematik (systematic risk) dari suatu sekuritas atau portofolio relatip terhadap risiko pasar.

Risiko pada umumnya dapat digolongkan menjadi tiga jenis risiko yang diperhitungkan dalam analisis penganggaran barang modal, yaitu risiko berdiri sendiri, risiko perusahaan atau internal perusahaan, dan risiko beta atau risiko pasar. Secara teoritis investor yang mendiversivikasikan sahamnya dengan baik hanya perlu memperhitungkan risiko beta atau risiko pasar dan manajer hanya perlu memikirkan pemaksimuman harga saham. Kedua faktor ini akan mengarah kepada kesimpulan bahwa risiko beta atau risiko pasar merupakan pokok pertimbangan utama dalam penganggaran barang modal.

Risiko beta dapat dihitung dengan menggunakan Model Indeks Tunggal dengan mengukur korelasi antar saham dengan cara tidak langsung, yaitu dengan melihat korelasi antara return saham dengan faktor tertentu yang mempengaruhi semua saham (Ashidiqi, 2013).

\section{Likuiditas Saham}

Likudiitas saham diartikan sebagai kemudaham dalam perdagangan saham perusahaan di Bursa Efek Indonesia (BEI). Likuiditas saham merupakan ukuran dari jumlah transaksi saham yang ada di pasar modal dalam suatu periode tertentu (Efrina dan Faisal, 2017). Hal ini berarti semakin likuid saham suatu perusahaan maka frekuensi transaksi saham tersebut juga semakin tinggi (Ferdian, 2012). Frekuensi perdagangan saham akan sangat berpengaruh pada jumlah lembar saham yang beredar. Selain itu, jumlah saham beredar akan secara tidak langsung berpengaruh terhadap volume perdagangan saham karena tingginya tingkat minat investor terhadap saham tersebut. Sehingga dapat dikatakan bahwa saham perusahaan yang mempunyai tingkat volume perdagangan yang tinggi memiliki tingkat likuiditas tinggi juga.

Pengukuran likuiditas saham yang dilakukan oleh pelaku pasar yang satu dengan yang lain biasanya tidak sama. Sebagian pelaku pasar mengukur likuiditas saham dengan cara kemudahan dan kecepatan transaksi dari saham. Selain itu, sebagian mengukur likuiditas saham dengan menghubungkannya dengan volume transaksi saham. Namun BEI menggunakan volume perdagangan, frekuensi, dan jumlah hari transaksi sebagai ukuranukuran likuiditas saham sehingga semakin tinggi frekuensi maka semakin tinggi tingkat likuiditas saham tersebut (Efrina dan Faisal, 2017).

Trading Volume Activity (TVA) merupakan suatu instrument yang dapat digunakan untuk melihat reaksi pasar terhadap suatu informasi melalui parameter pergerakan aktivitas voleme perdagangan di pasar modal dikarenakan nilai TVA berbanding lurus dengan likudiitas saham semakin tinggi nilai TVA sebuah saham maka hal itu berarti saham tersebut 
dapat dijual dengan mudah karena banyak yang bersedia membeli saham sehingga saham mudah dikonversikan menjadi uang kas. Perhitungan TVA dilakukan dengan membandingan jumlah saham yang diperdagangkan dalam suatu periode tertentu dengan keseluruhan jumlah saham beredar di perusahaan tersebut pada kurun waktu yang sama (Efrina dan Faisal, 2017).

\section{Independensi Dewan Komisaris}

Menurut Komite Nasional Kebijakan Good Corporate Governance, Dewan komisaris independen adalah anggota komisaris yang tidak terafiliasi dengan manajemen, anggota komisaris lainnya dan pemegang saham pengendali, serta bebas dari hubungan bisnis dan hubungan lainnya yang dapat mempengaruhi kemampuan untuk bertindak independen atau semata-mata bertindak hanya untuk kepentingan dari perusahaan tersebut (Nurfadilla, 2016). Dewan Komisaris memiliki fungsi untuk memastikan bahwa kegiatan operasional perusahaan telah berjalan sesuai dengan kebijakan perusahaan (Riniati, 2015). Pengangkatan dan pemberhentian dewan komisaris dalam suatu perusahaan dilakukan oleh RUPS. Komposisi dewan komisaris dalam perusahaan akan disusun sedemikian rupa sehingga pengambilan keputusan dapat dilakukan dengan efektif, tepat, dan cepat serta secara independen (Riniati, 2015). Masa jabatan dewan komisaris ditetapkan selama 5 tahun dan dapat menjabat kembali untuk 1 kali masa jabatan.

Anggota dewan komisaris yang telah terbentuk sewaktu-waktu dapat diberhentikan dengan keputusan oleh RUPS. Ketentuan lainnya mengenai mengenai persyaratan serta tata cara pengangkatan dan pemberhentian dewan komisaris diatur dengan Keputusan Menteri. Dewan komisaris akan bertugas untuk mengawasi dewan direksi dalam menjalankan tugasnya dalam kepengurusan perusahaan serta memberikan nasihat kepada Direksi. Anggaran dasar yang menjadi acuan dalam pelaksanaan tugas dewan komisaris dapat ditetapkan dengan memberikan wewenang kepada dewan komisaris untuk menyetujui direksi dalam melakukan perbuatan tertentu. Berdasarkan anggaran dasar tersebut, dewan komisaris dapat melakukan peran sebagai pengurus perusahaan dalam keadaan tertentu dan hanya untuk jangka waktu tertentu.

Anggota dewan komisaris selama masih menjabat akan dilarang untuk memiliki jabatan rangkap sebagai (a) anggota Direksi pada BUMN, BUMD, BUMS, dan jabatan lain yang mungkin dapat menimbulkan konflik benturan kepentingan (b) jabatan lainnya yang telah diatur dalam peraturan perundang-undangan. Dewan komisaris adalah wakil dari pemegang saham dalam sebuah perusahaan yang berbentuk Perseroan Terbatas (PT). Dewan komisaris ini berfungsi untuk mengawasi pengelolaan data perusahaan yang dilaksanakan oleh manajemen (direksi). Dewan komisaris dinyatakan independen jika bebas dari hubungan bisnis atau hubungan lainnya yang mungkin dapat memepengaruhi independensinya.

Keberadaan komisaris independen dalam perusahaan juga berfungsi sebagai penyeimbang dalam proses pengambilan keputusan guna memberikan perlindungan terhadap pemegang saham minoritas dan pihak-pihak lain yang terkait dengan perusahaan (Mayangsari et al. dalam Winarto, 2010). Menurut Raniati (2015) tanggung jawab dewan komisaris independen adalah mendorong diterapkannya prinsip tata kelola perusahaan yang baik (Good Corporate Governance) di dalam perusahaan melalui pemberdayaan dewan komisaris agar dapat melakukan tugas pengawasan dan pemberian nasihat kepada direksi secara efektif dan lebih memberikan nilai tambah bagi perusahaan. 


\section{Komite Audit}

Pengertian komite audit menurut keputusan Bursa Efek Indonesia melalui Kep.Direksi BEJ No. Kep-315/BEJ/06/2000 dalam Akbar (2014) adalah komite yang dibentuk oleh dewan komisaris perusahaan, yang anggotanya diangkat dan diberhentikan oleh dewan komisaris, yang bertugas membantu melakukan pemeriksaan atau penelitian yang dianggap perlu terhadap pelaksanaan fungsi direksi dalam pengelolaan perusahaan.

Komite audit dibentuk dengan tujuan utama yaitu untuk membantu dewan komisaris dalam melakukan pengawasan atas kinerja perusahaan. Menurut Bapepam anggota komite audit yang mempunyai setidaknya satu ahli keuangan dapat meningkatkan efektivitas komite audit dalam melakukan tugas pengawasan (Prastiti dan Meiranto, 2013).

Menurut Bapepam dalam Prastiti dan Meiranto (2013) anggota komite audit yang mempunyai setidaknya satu ahli keuangan dapat meningkatkan efektivitas komite audit dalam melakukan tugas pengawasan. The Sarbanes Oxley Act juga menjelaskan pengertian terkait ahli akuntansi atau keuangan dalam komite audit namun tidak memberikan kriteria yang pasti mengenai orang yang dapat disebut sebagai "financial expert" (Akbar, 2014). Akbar (2014) menjelaskan UU ini hanya meminta SEC merumuskan kriteria "financial expert" dengan menekankan beberapa hal berikut :

1. Memiliki pengalaman sebelumnya sebagai akuntan publik atau auditor, CFO, controller chief.

2. Accounting officer atau posisi yang sejenis.

3. Pemahaman terhadap standar akuntansi keuangan dan laporan keuangan.

4. Pengalaman dalam audit atas laporan keuangan perusahaan.

5. Pengalaman dalam pengendalian internal.

6. Pemahaman atas akuntansi untuk penaksiran (estimates), accruals, dan cadangan (reserves).

Berdasarkan pengertian diatas maka perusahaan setidaknya terdapat anggota dari komite audit yang ahli dalam bidang keuangan dimana memiliki pengetahuan dan kompetensi dibidang akuntansi, keuangan, dan pengauditan sehinggga dapat mengidentifikasi dan memberikan pertanyaan yang relavan kepada manajemen dan auditor eksternal agar dapat menjamin pelaporan keuangan.

\section{Beta Saham dan Biaya Modal Ekuitas}

Tingginya risiko dari suatu perusahaan akibat tingginya asimetri informasi akan menyebabkan investor akan sulit percaya kepada informasi yang disajikan oleh perusahaan. Teori sinyal menjelaskan bahwa asimetri informasi antara perusahaan dan investor dapat terjadi apabila perusahaan tidak mengungkap informasi sebagaimana keadaan perusahaan yang sesungguhnya sebagai sinyal bagi investor yang akan menanamkan modalnya (Dewi dkk, 2017). Semakin tinggi asimetri informasi yang terjadi juga akan menyebabkan investor kurang percaya bahwa nilai saham yang ada di pasar modal telah mencerminkan keadaan perusahaan yang sesungguhnya. Hal ini yang akhirnya menyebabkan investor menilai perusahaan jauh dari keadaan perusahaan yang sesungguhnya (nilai intrinsik perusahaan) sehingga selisih antara penilaian investor dan ekspektasi dari perusahaan atas nilai saham di pasar modal semakin tinggi sehingga biaya modal ekuitas juga semakin tinggi.

Hasil penelitian Dewi et al. (2017), Yanesari et al. (2012), dan Fahdiansah (2016) yang meneliti mengenai pengaruh beta saham terhadap biaya modal ekuitas menunjukkan hasil bahwa beta saham berpengaruh positif terhadap biaya modal ekuitas. Hal ini berarti semakin tinggi risiko atau beta saham dari sebuah perusahaan, maka akan semakin besar tingkat 
pengembalian yang diharapkan oleh investor. Berdasarkan argumentasi di atas maka hipotesis yang digunakan dalam penelitian ini adalah sebagai berikut :

\section{H1 : Beta saham berpengaruh positif terhadap biaya modal ekuitas.}

\section{Likuiditas Saham dan Biaya Modal Ekuitas}

Para investor yang tertarik terhadap suatu saham perusahaan yang likuid pasti telah mengikuti sepak terjang perusahaan di pasar modal dan percaya bahwa laporan keuangan perusahaan telah mencerminkan keadaan yang sesungguhnya. Apabila investor mengetahui kinerja perusahaan yang sesungguhnya, maka investor tidak akan merasa tertipu dan investor tidak akan menawar saham perusahaan dengan harga yang rendah melainkan dengan harga tinggi yang mungkin mendekati nilai perusahaan itu sendiri.

Selain itu, tingginya tingkat likuiditas saham juga menandakan bahwa penawaran (supply) dan permintaan (demand) terjadi secara aktif atas suatu saham perusahaan di pasar modal. Saham perusahaan yang aktif diperdagangkan di pasar modal tidak akan mudah mengalami penurunan nilai. Nilai saham yang tidak mudah mengalami penurunan akan dianggap memiliki kinerja yang baik atau stabil sehingga hal tersebut akan diterima oleh pasar sebagai sinyal yang baik. Perusahaan yang dapat menunjukkan kinerjanya di pasar modal melalui nilai saham yang stabil akan semakin mendorong kepercayaan investor bahwa hal tersebut telah mencerminkan keadaan perusahaan yang sebenarnya. Kepercayaan investor tersebut menyebabkan penilaian investor terhadap perushaan akan semakin mendekati nilai intrinsiknya. Apabila investor menilai perusahaan mendekati nilai intrinsiknya, maka selisih dari apa yang diharapkan oleh perusahaan dan kenyataan yang ada di pasar modal menjadi semakin kecil sehingga biaya modal ekuitas perusahaan juga semakin kecil.

Menurut Kirana (2013) biaya modal ekuitas sangat penting karena dapat berpengaruh kepada kualitas dan nilai dari sebuah perusahaan. Hal ini dikarenakan biaya modal ekuitas akan semakin rendah dengan adanya tingkat likuiditas yang tinggi sehingga investor akan berasumsi bahwa perusahaan tersebut memiliki kualitas dan nilai perusahaan yang baik. Hasil penelitian dari Fard (2017), Efrina dan Faisal (2017), dan Zorn (2007) mengenai pengaruh likuiditas saham terhadap biaya modal ekuitas menjelaskan bahwa likuditas saham yang semakin tinggi maka menyebabkan biaya modal ekuitas perusahaan untuk investor akan semakin kecil. Berdasarkan argumentasi di atas maka hipotesis yang digunakan dalam penelitian ini adalah sebagai berikut :

\section{H2 : Likuiditas saham berpengaruh negatif terhadap biaya modal ekuitas}

\section{Ukuran KAP dan Biaya Modal Ekuitas}

Di Indonesia, KAP Big four dianggap sebagai KAP yang besar karena lebih berkualitas dengan memberikan pelayanan yang terbaik. Menurut Sanjaya (2017) KAP Big Four berbeda dengan KAP lain, KAP Big Four akan lebih berinvestasi untuk reputasi modalnya. KAP Big Four akan berinvestasi dalam pengetahuan industri yang spesifik berpotensi memberikan auditor kemampuan untuk memberikan jasa dengan kualitas audit yang lebih tinggi (Desiliani dan Meiranto, 2015). Kualitas audit akan meningkat dengan adanya hubungan yang erat antar auditor dengan klien (Desiliani, 2014). Auditor spesialisasi industri cenderung melakukan investasi yang lebih besar dalam rekrutmen pegawai, pelatihan, teknologi informasi dan teknologi audit daripada auditor non spesialisasi industri supaya lebih dapat mendeteksi adanya praktik manajemen laba (Kirana, 2013).

KAP Big Four memiliki insentif yang lebih besar dalam melakukan audit atas laporan keuangan yang lebih akurat karena KAP Big Four telah memiliki banyak hubungan spesifik dengan klien (client specific rents) yang akan hilang apabila memberikan hasil audit yang 
tidak akurat (Muhammad, 2014). Selain itu, KAP Big Four juga memiliki sumber daya atau kekayaan yang lebih besar daripada KAP Non Big Four sehingga KAP Big Four lebih terancam (exposed) akan tuntutan hukum pihak ketiga apabila menghasilkan laporan audit yang tidak akurat (Putri, 2012). KAP Big Four dipandang sebagai KAP yang menghasilkan tingkat reliabilitas yang tinggi sehingga berdampak pada tingkat kepercayaan investor terhadap pihak manajemen (Purnomo, 2012)

Laporan keuangan yang diaudit dari KAP Big Four dipercaya oleh pasar dapat menjamin bahwa informasi yang disajikan perusahaan telah wajar sehingga asimetri informasi antara manajemen dan pemangku kepentingan juga akan menjadi semakin kecil. Asimetri informasi yang semakin kecil akan mendorong investor semakin percaya terhadap informasi yang disajikan termasuk percaya bahwa informasi nilai saham yang ada di pasar modal telah mencerminkan keadaan perusahaan yang sesungguhnya. Kepercayaan investor tersebut akan mendorong ekspektasi investor atas suatu perusahaan mendekati nilai intrinsiknya (keadaan perusahaan yang sesungghnya). Hal ini yang kemudian akan menyebabkan selisih antara penilaian investor dan ekspektasi perusahaan akan semakin kecil sehingga biaya modal ekuitas juga akan semakin kecil.

Hasil penelitian Fernando et al. (2010), Yanesari (2012), dan Desiliani (2014) mengenai pengaruh ukuran KAP terhadap biaya modal ekuitas menjelaskan bahwa ukuran KAP berpengaruh negatif terhadap biaya modal ekuitas. Pengaruh tersebut menunjukkan pengaruh ukuran KAP dapat mengurangi biaya modal ekuitas. Berdasarkan argumentasi di atas maka hipotesis yang digunakan dalam penelitian ini adalah sebagai berikut :

\section{H3 : Ukuran KAP berpengaruh negatif terhadap biaya modal ekuitas.}

\section{Auditor Spesialisasi Industri dan Biaya Modal Ekuitas}

Spesialisasi industri dari seorang auditor dipercaya dapat mencerminkan bahwa auditor tersebut memiliki reputasi yang baik sehingga dapat memberikan pelayanan terjamin karena memiliki pemahaman, pengetahuan, dan pengalaman yang lebih mengenai masalah-masalah khusus yang ada dalam sebuah industri yang spesifik. Auditor yang memiliki spesialisasi industri juga dapat mendeteksi kesalahan dalam sebuah industri yang spesifik sehingga tingkat kepercayaan investor.

Klien yang laporan keuangannya diaudit oleh auditor dengan spesialisasi industri memiliki discretional accrual yang lebih rendah dan earning reponse coefficient (ERC) yang lebih tinggi daripadi klien tanpa auditor dengan spesialisasi industri (Kirana, 2013). Berdasarkan teori sinyal, saat investor telah menerima sinyal tersebut, investor akan melakukan proses interpretasi dan analisis atas informasi yang diberikan dan dapat mengurangi tingkat asimetri informasi (Kirana, 2013). Tingkat asimetri yang semakin rendah juga akan semakin meyakinkan investor pada perusahaan termasuk mengenai nilai sahamnya. Investor akan percaya bahwa nilai saham yang ada di pasar modal telah mencerminkan keadaan perusahaan yang sesungguhnya sehingga penilaian investor terhadap perusahaan tersebut akan semakin mendekati nilai intrinsiknya. Perusahaan yang dinilai mendekati nilai intrinsiknya akan mengakibatkan selisih antara ekspektasi perusahaan atas nilai saham di pasar modal dan penilaian investor menjadi semakin kecil sehingga akan menyebabkan biaya modal ekuitas menjadi rendah.

Hasil penelitian dari Fernando et al. (2010), Herusetya (2012), dan Khan et al. (2014) mengenai bagaimana pengaruh spesialisasi industri auditor dan hasilnya menjelaskan bahwa spesialisasi industri auditor memiliki pengaruh negatif terhadap biaya modal ekuitas yang artinya auditor dengan kemampuan spesialisasi industri akan dapat menekan biaya modal 
ekuitas. Berdasarkan argumentasi di atas maka hipotesis yang digunakan dalam penelitian ini adalah sebagai berikut :

\section{H4 : Auditor spesialisasi industri berpengaruh negatif terhadap biaya modal ekuitas.}

\section{Independensi Dewan Komisaris dan Biaya Modal Ekuitas}

Dewan Komisaris merupakan badan yang menjalankan fungsi pengawasan di dalam perusahaan. Sebagai wakil pemegang saham, Dewan Komisaris diharapkan mencegah perilaku manajemen yang bersifat oportunis (Chairunnisa, 2014). Semakin banyak jumlah dewan komisaris yang berasal dari luar maka fungsi pengawasan yang dilakukan akan semakin efektif (Zulfikar, 2016). Investor akan lebih percaya pada informasi perusahaan yang memiliki banyak anggota komisaris independen sehingga asimetri informasi semakin kecil. Tingkat asimetri yang semakin rendah akan meyakinkan investor bahwa informasi nilai saham yang ada di pasar modal telah mencerminkan keadaan perusahaan yang sesungguhnya sehingga penilaian investor terhadap perusahaan juga akan semakin mendekati nilai intrinsiknya. Penilaian investor terhadap perusahaan yang hampir mendekati nilai intrinsiknya akan menyebabkan selisih antara ekspektasi perusahaan dengan realita yang ada sehingga hal inilah dapat menekan biaya modal ekuitas.

Penelitian Chairunnisa (2014), Winarto (2012), dan Rosita (2016) menunjukkan bahwa dewan komisaris independen memiliki pengaruh negatif terhadap cost of equity capital. Hasil penelitian tersebut menunjukkan bahwa keberadaan komisaris independen meningkatkan fungsi pengawasan Dewan Komisaris sehingga dapat menurunkan biaya ekuitas. Berdasarkan argumentasi di atas maka hipotesis yang digunakan dalam penelitian ini adalah sebagai berikut :

\section{H5 : Independensi dewan komisaris berpengaruh negatif terhadap biaya modal ekuitas.}

\section{Keahlian Komite Audit dan Biaya Modal Ekuitas}

Menurut Wardani (2015), salah satu tugas utama komite audit adalah untuk mengawasi proses keuangan perusahaan, maka anggota komite audit yang memiliki keahlian keuangan (terutama keahlian akuntansi) tentunya lebih efektif dalam memonitor manajemen dalam praktek pelaporan keuangan untuk menghasilkan laporan keuangan yang berkualitas tinggi.

Komite audit dengan keahlian keuangan memiliki dapat mengurangi praktik manajemen laba sehingga dapat meningkatkan kepercayaan investor (Pujiningsih, 2011). Tingginya kepercayaan investor yang tinggi akan mendorong investor semakin percaya bahwa angka laporan keuangan dan nilai saham perusahan di pasar modal telah menunjukkan kinerja perusahaan sesungguhnya sehingga terjadinya asimetri informasi antara pihak manajemen dan investor dapat ditekan. Tingkat asimteri yang semakin kecil akan menyebabkan investor menilai perusahaan semakin mendekati nilai intrinsik perusahaan. Investor yang menilai perusahaan hampir mendekati nilai sesungguhnya dari perusahaan tersebut maka akan menyebabkan selisih antara ekspektasi perusahaan dengan realita yang ada di pasar modal akan semakin kecil. Hal inilah yang kemudian akan menyebabkan biaya modal ekuitas juga semakin kecil.

Penelitian Xiao (2014) serta Khemakhem dan Naciri (2015) menemukan bahwa keahlian komite audit berpengaruh negatif terhadap biaya modal ekuitas. Hasil penelitian tersebut menjelaskan bahwa dengan keahlian yang dimiliki oleh komite audit dapat menekan biaya modal ekuitas perusahaan karena komite audit dapat melaksanakan fungsi pengawasan dan pencegahan kecurangan yang ada dalam perusahaan. Sari dan Vera (2014) juga menemukan bahwa keahlian komite audit yang mencerminkan transparansi manajemen 
berpengaruh negatif terhadap biaya modal ekuitas. Oleh karena itu, berdasarkan argumentasi di atas maka hipotesis yang digunakan dalam penelitian ini adalah sebagai berikut:

H6 : Keahlian komite audit berpengaruh negatif terhadap biaya modal ekuitas.

\section{METODA PENELITIAN}

\section{Populasi dan Sampel Penelitian}

Populasi yang digunakan dalam penelitian ini adalah semua perusahaan yang terdaftar di Bursa Efek Indonesia. Sampel dalam penelitian ini adalah perusahaan yang terdaftar dalam BEI periode tahun 2013 - 2016 dengan kriteria tertentu atau dengan metode purposive sampling. Kriteria untuk pemilihan sampel adalah:

1. Perusahaan yang terdaftar di BEI selama periode 2013-2016.

2. Perusahaan yang mempublikasikan financial report dan annual report untuk periode 2013-2016.

3. Informasi yang dibutuhkan mengenai data variabel-variabel tersedia dengan lengkap.

4. Perusahaan yang memiliki cost of equity capital (COE) positif.

Kriteria pengambilan sampel secara lengkap dapat dilihat pada tabel 3.1. Total observasi yang digunakan adalah 1.171.

Tabel 3.1

Kriteria Pengambilan Sampel

\begin{tabular}{|l|c|c|c|c|c|}
\hline \multicolumn{1}{|c|}{ Keterangan } & $\mathbf{2 0 1 3}$ & $\mathbf{2 0 1 4}$ & $\mathbf{2 0 1 5}$ & $\mathbf{2 0 1 6}$ & Total \\
\hline Perusahaan yang terdaftar di BEI & 486 & 509 & 525 & 539 & 2.059 \\
\hline Perusahaan yang tidak menerbitkan LK & $(2)$ & - & $(1)$ & $(24)$ & $(27)$ \\
\hline Informasi yang tidak tersedia & $(165)$ & $(154)$ & $(165)$ & $(168)$ & $(652)$ \\
\hline Perusahaan dengan COE negatif & - & - & $(209)$ & - & $(209)$ \\
\hline Jumlah Sampel & $\mathbf{3 1 9}$ & $\mathbf{3 5 5}$ & $\mathbf{1 5 0}$ & $\mathbf{3 4 7}$ & $\mathbf{1 . 1 7 1}$ \\
\hline
\end{tabular}

Data yang digunakan pada penelitian ini adalah data sekunder yang didapat dari kantor IDX Semarang atau www.idx.co.id. Data tersebut juga akan didapat dari masing-masing website perusahaan. Selain itu, data lainnya seperti nama KAP yang mengaudit akan diperoleh dari ICMD (Indonesia Capital Market Directory). Sedangkan data beta saham perusahaan akan diambil dari website Pemeringkat Efek Indonesia (Pefindo) yaitu www.pefindo.com.

\section{Pengukuran Variabel}

\section{Biaya Modal Ekuitas (Y)}

Biaya modal merupakan rata-rata biaya dana yang dikeluarkan untuk melakukan suatu investasi (Putri, 2013). Menurut Sari dan Diyanty (2014) model COE dengan pendekatan Capital Asset Pricing Model (CAPM) dengan rumus sebagai berikut:

$$
\mathrm{COE}=\mathrm{Rf}_{\mathrm{t}}+\beta_{\mathrm{i}}\left(\mathrm{Rm}_{\mathrm{t}}-\mathrm{Rf}_{\mathrm{t}}\right)
$$

Keterangan :

COE : Cost of Equity

$\mathrm{Rf}_{\mathrm{t}} \quad$ : return bebas risiko yang diproksikan dengan tingkat suku bunga ORI (Obligasi Ritel Indonesia) per tahun.

$\mathrm{RM}_{\mathrm{t}} \quad$ : return pasar yang diperoleh dari indeks harga saham gabungan (IHSG) pada hari t 
dikurangi IHSG pada $\mathrm{t}-1$ dibagi dengan IHSG pada $\mathrm{t}-1$.
$\beta_{\mathrm{i}} \quad$ : risiko sistematis untuk setiap saham perusahaan i.

\section{Beta Saham (X1)}

Beta merupakan ukuran risiko sistematis suatu sekuritas yang tidak dapat dihilangkan dengan melakukan diversifikasi (Nurjanah dan Rosita, 2008). Data beta saham yang digunakan dalam penelitian ini akan diperoleh dengan mengambil data yang telah disediakan oleh Pemeringkat Efek Indonesia (Pefindo) pada www.pefindo.com.

\section{Likuiditas Saham (X2)}

Menurut Ferdian (2012) likuiditas saham adalah ukuran jumlah transaksi suatu saham perusahaan yang ada di pasar modal dalam suatu periode tertentu. likuiditas saham diukur dengan menggunakan Trading Volume Activity (TVA). TVA dapat dihitung dengan rumus sebagai berikut :

$$
\mathrm{TVA}=\frac{\text { Volume saham i diperdagangkan padawaktut }}{\text { Jumlah Saham perusahaan } \mathrm{i} \text { beredar padawaktu } t}
$$

\section{Ukuran Kantor Akuntan Publik (X3)}

Ukuran KAP diukur dengan variabel dummy yaitu 1 untuk perusahaan yang diaudit oleh KAP Big Four dan 0 untuk perusahaan yang diaudit oleh KAP Non Big Four. KAP di Indonesia yang berafiliasi dengan KAP Big Four pada tahun 2013 - 2016 antara lain adalah:

1. KAP Ernst and Young International di Indonesia berafiliasi dengan Purwantono, Suherman, dan Surja.

2. KAP Price Waterhouse Coopers di Indonesia berafiliasi dengan Tanudireja, Wibisono, dan rekan.

3. KAP Klynveld Peat Marwick Goeldener International (KPMG) di Indonesia berafiliasi dengan Sidharta dan Widjaja.

4. KAP Delloitte, Touche, and Tohmatsu di Indonesia berafiliasi dengan Osman, Bing, Satrio, dan rekan.

\section{Spesialisasi Industri Auditor (X4)}

Spesialisasi industri mengacu pada pengetahuan industri spesifik dan keahlian seorang auditor yang diperoleh dari audit yang luas dalam industri siapapun (Desiliani, 2014). Menurut Kirana (2013), Kantor Akuntan Publik (KAP) yang memiliki lebih dari 20\% market share di industri tertentu maka diklasifikasikan sebagai spesialis industri untuk industri tertentu. Pangsa pasar auditor spesialisasi auditor dihitung dengan rumus sebagai berikut:

$$
\underset{\text { Spesialisasi }}{\text { industri auditor }}=\frac{\text { Total aset klien KAP pada industri tertentu }}{\text { Jumlah total aset dlm industri tertentu }} x 100 \%
$$

Hasil perhitungan kemudian akan diukur dengan variabel dummy dimana 1 untuk perusahaan diaudit oleh auditor spesialisasi industri dan angka 0 untuk perusahaan yang diaudit oleh auditor non spesialisasi industri (Kirana, 2013).

\section{Independensi Dewan Komisaris (X5)}

Dewan komisaris independen adalah anggota komisaris yang tidak terafiliasi dengan manajemen, anggota komisaris lainnya dan pemegang saham pengendali, serta bebas dari hubungan bisnis dan hubungan lainnya yang dapat mempengaruhi kemampuan untuk bertindak independen atau semata-mata bertindak hanya untuk kepentingan dari perusahaan tersebut 
(Komite Nasional Kebijakan Good Corporate Governance dalam Nurfadilla, 2016). Menurut Riniati (2015) independensi dewan komisaris dihitung dapat rumus sebagai berikut :

$$
\text { Independensi DK }=\frac{\text { Jumlah anggota outsider commissioners }}{\text { Jumlah total anggota dewan komisaris }} \times 100 \%
$$

\section{Keahlian Komite Audit (X6)}

Keahlian komite audit merupakan keahlian komite audit dalam bidang keuangan atau akuntansi yang dapat meningkatkan efektivitas untuk melakukan perannya dalam perusahaan. Pada penelitian ini keahlian komite audit akan diukur dengan menggunakan variabel dummy yaitu 1 ubtuk anggota komite audit yang memiliki pendidikan dalam bidang keuangan atau akuntansi dan 0 untuk anggota komite audit yang tidak memiliki latar belakang pendidikan dalam bidang keuangan atau akuntansi.

\section{Ukuran Perusahaan}

Ukuran perusahaan adalah besar kecilnya perusahaan dilihat dari nilai equity, nilai penjualan, atau nilai total aktiva. Rumus penilaian ukuran perusahaan adalah sebagai berikut:

$$
\mathrm{SIZE}=\log \text { of total assets }
$$

\section{Profitabilitas}

Profitabilas merupakan gambaran dari kinerja manajemen dalam mengelola perusahaan. Dalam penelitian ini, profitabilitas diukur menggunakan rasio ROA (return on assets). Rumus ROA sebagai berikut :

$$
\mathrm{ROA}=\frac{\text { Laba setelah pajak }}{\text { Total asset }}
$$

\section{Leverage}

Leverage merupakan pengukur besarnya aktiva yang dibiayai dengan hutang-hutang yang digunakan untuk membiayai aktiva berasal dari kreditur, bukan dari pemegang saham ataupun dari investor. Rumus leverage sebagai berikut :

$$
\mathrm{LEV}=\frac{\text { Total liabilities }}{\text { Total asset }}
$$

\section{Model Penelitian}

Analisis regresi digunakan untuk dapat mengetahui seberapa besar pengaruh yang terjadi antara variabel independen dengan variabel dependen serta untuk mengetahui arah hubungan tersebut. Persamaan regresi yang digunakan dalam penelitian ini adalah sebagai berikut:

$\mathrm{COE}_{i t}=\alpha+\beta_{1} \mathrm{BET}_{\text {it }}+\beta_{2} \mathrm{LIQ}_{\text {it }}+\beta_{3} \mathrm{UKP}_{\text {it }}+\beta_{4} \mathrm{SPI}_{\text {it }}+\beta_{5} \mathrm{IDK}_{\text {it }}+\beta_{6} \mathrm{KKA}_{\text {it }}+\beta_{7} \mathrm{SIZE}_{\text {it }}+\beta_{8} \mathrm{ROA}_{\text {it }}$ $+\beta_{9} \mathrm{LEV}_{\mathrm{it}}+\mathrm{e}$

Keterangan:

COE: Cost of Equity; BET : Beta saham perusahaan i pada tahun t yang diperoleh dari website pefindo; LIQ: Likuiditas saham perusahaan $\mathrm{i}$ pada tahun $\mathrm{t}$ yang dihitung 
menggunakan TVA; UKP: Ukuran KAP perusahaan i pada tahun t yang diukur menggunakan variabel dummy; SPI: Spesialisasi industri auditor untuk perusahaan i pada tahun t yang dihitung dengan menggunakan total aset klien industri tertentu dibagi dengan jumlah total aset industri tertentu; IDK: Independensi dewan komisaris perusahaan i pada tahun t yang dihitung menggunakan jumlah anggota outside directors dibagi jumlah anggota dewan komisaris; KKA: Keahlian komite audit perusahaan i pada tahun t yang diukur menggunakan variabel dummy; SIZE: Ukuran perusahaan i pada tahun t yang dihitung dengan log of total asset; ROA: Profitabilitas perusahaan i pada tahun t yang diukur dengan Return of Asset; LEV: Leverage perusahaan i pada tahun t yang diukur menggunakan rasio leverage.

\section{HASIL DAN PEMBAHASAN}

\section{Statistik Deskriptif}

Analisis statistik deskriptif ini dilakukan untuk mengetahui pola penyebaran variabel variabel penelitian. Dari jumlah data awal sebanyak 1.171, ada 371 yang harus dikularkan untuk memenuhi asumsi normalitas. Data akhir yang digunakan dalam penelitian ini menjadi sebanyak 800 perusahaan. Tabel 4.1, 4.2, 4.3, dan 4.4 menyajikan statistik deskriptif variabelvariabel penelitiain.

Berdasarkan tabel 4.1 variabel dependen cost of equity (COE) memiliki nilai minimum sebesar 0,00 dan nilai maksimum sebesar 0,94. Rata-rata COE sebesar 13\% tersebut menunjukkan bahwa perusahaan menanggung biaya modal ekuitas yang tergolong cukup tinggi untuk dapat memperoleh modal yang berasal investasi dari investor.

Hasil perhitungan data beta saham menunjukkan nilai terendah sebesar 0,334 dan nilai tertinggi sebesar 2,40. Sedangkan nilai standar deviasinya sebesar 0,33 dan rata-ratanya sebesar 0,75. Rata-rata variabel beta saham tersebut kurang dari 1 sehingga hal ini menunjukkan bahwa rata-rata perusahaan kurang memiliki sinkronisitas antara kinerja saham individual perusahaan dengan pergerakan return di pasar.

Kemudian hasil perhitungan variabel likuiditas saham memberikan nilai minimum sebesar 0,000001025 dan nilai maksimumnya adalah 0,77. Nilai standar deviasi variabel ini sebesar 0,08 dan nilai rata-rata sebesar $4 \%$. Hal tersebut menunjukkan rata-rata frekuensi jual beli saham perusahaan yang dilakukan oleh investor di pasar modal sebesar $4 \%$.

Variabel kontrol ukuran perusahaan (SIZE) memiliki nilai minimum sebesar 4,40 dan nilai maksimum sebesar 9,02. Sedangkan standar deviasinya adalah sebesar 0,76 dan rata-rata sebesar 6,41 yang menunjukkan bahwa perusahaan memiliki aset yang cukup besar untuk dapat menjalankan kegiatan operasionalnya.

Variabel kontrol profitabilitas (ROA) menunjukkan nilai terendah sebesar -7,75 dan nilai tertinggi sebesar 2,49. Sedangkan standar deviasi sebesar 0,31 serta rata-rata sebesar 0,03 yang menandakan bahwa rata-rata kemampuan perusahaan dalam mengelola asetnya untuk menghasilkan laba adalah sebesar 3\%.

Variabel kontrol lainnya yaitu leverage (LEV) yang menunjukkan nilai minimum sebesar 0,00458 dan nilai maksimum sebesar 5,06. Standar deviasi variabel ini adalah sebesar 0,44 dan rata-ratanya adalah sebesar 0,55. Hal ini menandakan bahwa setiap Rp 1 aset digunakan untuk menjamin $\mathrm{Rp} 0,55$ hutang perusahaan. 


\section{Tabel 4.1}

Statistik Deskriptif

\begin{tabular}{|c|c|c|c|c|c|}
\hline Variabel & $\mathbf{N}$ & $\begin{array}{c}\text { Nilai } \\
\text { Minimum }\end{array}$ & $\begin{array}{c}\text { Nilai } \\
\text { Maksimum }\end{array}$ & $\begin{array}{c}\text { Rata- } \\
\text { rata }\end{array}$ & $\begin{array}{c}\text { Standar } \\
\text { Deviasi }\end{array}$ \\
\hline COE & 800 & 0,00 & 0,94 & 0,13 & 0,17 \\
\hline BET & 800 & 0,33 & 2,40 & 0,75 & 0,33 \\
\hline LIQ & 800 & 0,00 & 0,77 & 0,04 & 0,08 \\
\hline UKP & 800 & 0,00 & 1,00 & 0,40 & 0,49 \\
\hline SPI & 800 & 0,00 & 1,00 & 0,29 & 0,45 \\
\hline IDK & 800 & 0,00 & 1,00 & 0,42 & 0,13 \\
\hline KKA & 800 & 0,00 & 1,00 & 0,91 & 0,29 \\
\hline SIZE & 800 & 4,40 & 9,02 & 6,41 & 0,76 \\
\hline ROA & 800 & $-7,75$ & 2,49 & 0,03 & 0,31 \\
\hline LEV & 800 & 0,00 & 5,06 & 0,55 & 0,44 \\
\hline
\end{tabular}

Sumber : Data Sekunder yang diolah (2018)

Berdasarkan tabel 4.2 penelitian ini menunjukkan bahw perusahaan yang diaudit oleh KAP yang berafiliasi dengan KAP Big 4 sebanyak 40,1\% atau sebanyak 321 perusahaan. Sedangkan perusahaan yang diaudit oleh KAP non Big 4 adalah sebesar 59,9\% atau sebanyak 479 perusahaan. Hal tersebut tersebut menunjukkan bahwa secara rata-rata, perusahaan sampel pada penelitian ini lebih banyak menggunakan jasa audit dari KAP Non Big 4 dari pada jasa audit KAP Big 4.

Tabel 4.2

Frekuensi Ukuran KAP

\begin{tabular}{|ll|r|r|r|r|}
\hline & Frequency & Percent & Valid Percent & Cumulative Percent \\
\hline Valid & KAP Non Big 4 & 479 & 59.9 & 59.9 & 59.9 \\
& KAP Big 4 & 321 & 40.1 & 40.1 & 100.0 \\
& Total & 800 & 100.0 & 100.0 & \\
\hline
\end{tabular}

Berdasarkan tabel 4.3 variabel spesialisasi industri auditor dalam penelitian ini menunjukkan hasil bahwa perusahaan yang diaudit oleh auditor spesialisasi industri hanya $29,1 \%$ atau sebesar 233 perusahaan. Sedangkan perusahaan yang diaudit oleh auditor yang tidak memiliki spesialisasi adalah sebesar 70,9\% atau 567 perusahaan. Artinya, perusahaan yang menjadi sampel dari penelitian ini rata-rata diaudit oleh auditor yang tidak memiliki spesialisasi industri. Hasil pengujian variabel ini juga menunjukkan nilai standar deviasi sebesar 0.45 .

Tabel 4.3

Frekuensi Spesialisasi Industri Auditor

\begin{tabular}{|ll|r|r|r|r|}
\hline & & & \multicolumn{2}{|c|}{ Valid } & \multicolumn{2}{c|}{$\begin{array}{c}\text { Cumulative } \\
\text { Percent }\end{array}$} \\
\hline Valid & Non Spesialisasi & 567 & 70.9 & 70.9 & 70.9 \\
& Spesialisasi & 233 & 29.1 & 29.1 & 100.0 \\
& Total & 800 & 100.0 & 100.0 & \\
\hline
\end{tabular}

Hasil perhitungan variabel independen dewan komisaris menunjukkan nilai terendah $0 \%$ yang dimiliki oleh perusahaan dan nilai tertinggi $100 \%$. Sedangkan untuk nilai standar deviasi dan rata-ratanya masing-masing adalah sebesar 0,13 dan $42 \%$. Rata-rata dewan 
komisaris independen menunjukkan bahwa $42 \%$ dari anggota dewan komisaris pada perusahaan sampel penelitian ini adalah dewan komisaris independen.

\section{Tabel 4.4}

\section{Frekuensi Keahlian Komite Audit}

\begin{tabular}{|ll|r|r|r|r|}
\hline & Frequency & Percent & Valid Percent & Cumulative Percent \\
\hline Valid & Tidak ahli & 72 & 9.0 & 9.0 & 9.0 \\
& Ahli & 728 & 91.0 & 91.0 & 100.0 \\
& Total & 800 & 100.0 & 100.0 & \\
\hline
\end{tabular}

Sumber : Data sekunder yang diolah (2018)

Berdasarkan tabel 4.4 maka dapat dilihat bahwa perusahaan yang memiliki anggota komite audit dengan latar belakang akuntansi atau keuangan adalah sebesar $91 \%$ atau 728 perusahaan dan perusahaan yang tidak memiliki anggota komite audit dengan latar belakang akuntansi atau keuangan hanya sebesar $9 \%$ atau sebesar 72 perusahaan. Frekuensi tersebut menunjukkan bahwa secara rata-rata perusahaan sampel pada penelitian ini memiliki anggota komite audit dengan latar belakang akuntansi atau keuangan.

\section{Uji Normalitas}

Menurut Ghozali (2006) uji normalitas dilakukan dengan tujuan untuk menguji apakah data penelitian yang digunakan telah terdistribusi normal atau tidak. Pengujian normalitas dalam penelitian ini menggunakan uji kolmogorov-smirnov dimana data akan dikatakan lolos atau telah terdistribusi normal apabila hasil uji ini menunjukkan nilai signifikansi lebih dari sama dengan 0,05.

Tabel 4.5

Uji Normalitas

\begin{tabular}{|l|r|r|r|r|r|r|}
\hline & \multicolumn{3}{|c|}{ Kolmogorov-Smirnov $^{\mathrm{a}}$} & \multicolumn{3}{c|}{ Shapiro-Wilk } \\
\cline { 2 - 7 } & Statistic & \multicolumn{1}{c|}{ Df } & \multicolumn{1}{c|}{ Sig. } & \multicolumn{1}{c|}{ Statistic } & df & \multicolumn{1}{c|}{ Sig. } \\
\hline $\begin{array}{l}\text { Unstandardized } \\
\text { Residual }\end{array}$ & .148 & 1171 & .000 & .892 & 1171 & .000 \\
\hline
\end{tabular}

Sumber : Data sekunder yang diolah (2018)

Dari tabel 4.5 dapat dilihat bahwa data awal yang tersedia berdasarkan kriteria pemilihan sampel yang berjumlah 1.171 tidak berdistribusi normal. Sebanyak 371 harus dieliminasi untuk menghasilkan distribusi data yang normal.

Tabel 4.6

\section{Pengujian Kembali Normalitas}

\begin{tabular}{|l|r|r|r|r|r|r|}
\hline & \multicolumn{4}{|c|}{ Kolmogorov-Smirnova $^{\mathrm{a}}$} & \multicolumn{3}{c|}{ Shapiro-Wilk } \\
\cline { 2 - 7 } & Statistic & \multicolumn{1}{c|}{ Df } & \multicolumn{1}{c|}{ Sig. } & Statistic & df & Sig. \\
\hline $\begin{array}{l}\text { Unstandardized } \\
\text { Residual }\end{array}$ & .028 & 800 & .157 & .990 & 800 & .000 \\
\hline
\end{tabular}

Sumber : Data sekunder yang diolah (2018)

Berdasarkan tabel 4.6 menunjukkan hasil nilai signifikansinya sebesar 0,157 dan dapat diketahui Asymp Sig untuk Standardized Residual yaitu sebesar 0,157 > 0.05 sehingga dapat disimpulkan bahwa data residual dalam penelitian ini telah terdistribusi normal. 


\section{Uji Multikolinearitas}

Uji multikolinearitas merupakan uji asumsi klasik yang digunakan untuk mengetahui apakah dalam model regresi penelitian ini terdapat hubungan atau korelasi diantara variabel independennya (Sanjaya, 2017). Pengujian ini dilakukan dengan menganalisa collinearity statistics pada nilai tolerance dan nilai Variance Inflation Factor (VIF). Data dikatakan lolos uji multikolinearitas apabila nilai tolerance $>0,1$ dan nilai $\mathrm{VIF}<10$.

\section{Tabel 4.7}

\section{Hasil Uji Multikolinieritas}

\begin{tabular}{|l|r|r|r|r|}
\hline \multirow{2}{*}{ Model } & \multicolumn{2}{|c|}{$\begin{array}{c}\text { Unstandardized } \\
\text { Coefficients }\end{array}$} & \multicolumn{2}{c|}{ Collinearity Statistics } \\
\cline { 2 - 5 } & \multicolumn{1}{c|}{ B } & $\begin{array}{c}\text { Std. } \\
\text { Error }\end{array}$ & Tolerance & \multicolumn{1}{c|}{ VIF } \\
\hline (Constant) & -.209 & .036 & & \\
BET & .425 & .011 & .885 & 1.130 \\
LIQ & .013 & .047 & .971 & 1.029 \\
UKP & .031 & .010 & .490 & 2.042 \\
SPI & -.042 & .011 & .508 & 1.969 \\
IDK & .054 & .028 & .970 & 1.031 \\
KKA & .001 & .013 & .989 & 1.011 \\
SIZ & .001 & .006 & .708 & 1.413 \\
ROA & -.021 & .012 & .953 & 1.049 \\
LEV & -.008 & .008 & .946 & 1.057 \\
\hline
\end{tabular}

Berdasarkan dari hasil tabel 4.7 di atas maka dapat dilihat hasil nilai tolerance semua variabel adalah $<1$ dan nilai VIF semua variabel tidak ada yang lebih besar dari pada 10 sehingga dapat disimpulkan bahwa tidak ada korelasi yang kuat antar variabel independen atau tidak terjadi multikolinearitas.

\section{Uji Autokorelasi}

Pengujian autokorelasi digunakan untuk melihat apakah ada korelasi diantara residual pada satu pengamatan dengan pengamatan lainnya yang terdapat pada model regresi (Ghoazali, 2006). Pengujian ini menggunakan uji Durbin-Watson. Dari tabel 4.8 nilai Durbin Watson $(\mathrm{DW})$ adalah sebesar 1,901 . Nilai $\mathrm{DL}=1,81571$ nilai $\mathrm{DU}=1,85601$ dan 4 -DU $=$ 2,14399 dengan $\mathrm{N}=800$ dan $\mathrm{K}=9$. Nilai $\mathrm{DW}$ sebesar 1,901 berada diantara $1,81571<\mathrm{DW}$ $<(4-1,85601)$ maka hasil pengujian ini dapat disimpulkan bahwa dalam model regresi penelitian ini tidak ada autokorelasi.

\section{Tabel 4.8}

\section{Hasil Uji Autokorelasi}

\begin{tabular}{|c|c|c|c|c|c|}
\hline Model & $\mathrm{R}$ & R Square & $\begin{array}{c}\text { Adjusted R } \\
\text { Square }\end{array}$ & $\begin{array}{c}\text { Std. Error of the } \\
\text { Estimate }\end{array}$ & Durbin-Watson \\
\hline 1 & $.819^{\mathrm{a}}$ & .671 & .667 & .100921 & 1.901 \\
\hline
\end{tabular}

Sumber : Data sekunder yang diolah (2018)

\section{Uji Heterokedastisitas}

Menurut Ghozali (2006) uji heterokedastisitas bertujuan untuk menguji apakah dalam suatu model regresi terjadi ketidaksamaan varian dari residual satu pengamatan ke pengamatan lainnya. Uji heterokedastisitas dalam penelitian ini menggunakan uji glejser dimana apabila hasil signifikansinya menunjukkan hasil lebih besar dari 0,05 maka dapat disimpulkan bahwa data bebas dari heterokedastisitas. 
Tabel 4.9

Hasil Uji Heterokedastisitas

\begin{tabular}{|c|c|c|c|c|c|}
\hline \multirow[b]{2}{*}{ Model } & \multicolumn{2}{|c|}{ Unstandardized Coefficients } & \multirow{2}{*}{$\begin{array}{c}\begin{array}{c}\text { Standardized } \\
\text { Coefficients }\end{array} \\
\text { Beta }\end{array}$} & \multirow[b]{2}{*}{$\mathrm{t}$} & \multirow[b]{2}{*}{ Sig. } \\
\hline & $\mathrm{B}$ & Std. Error & & & \\
\hline 1 (Constant) & .011 & .063 & & .176 & .861 \\
\hline BET & .028 & .020 & .054 & 1.446 & .149 \\
\hline LIQ & .069 & .081 & .031 & .858 & .391 \\
\hline UKP & -.012 & .018 & -.033 & -.663 & .508 \\
\hline SPI & .034 & .019 & .088 & 1.784 & .075 \\
\hline IDK & .038 & .048 & .028 & .791 & .429 \\
\hline KKA & .003 & .022 & .005 & .139 & .890 \\
\hline SIZ & .008 & .010 & .036 & .858 & .391 \\
\hline ROA & .019 & .020 & .034 & .949 & .343 \\
\hline LEV & .027 & .014 & .067 & 1.857 & .064 \\
\hline
\end{tabular}

Sumber : Data sekunder yang diolah (2018)

Hasil uji heterokedastisitas pada tabel 4.9 di atas menunjukan bahwa nilai signifikansi semua variabel lebih dari 0,05 . Hal tersebut menunjukan bahwa tidak ada masalah heteroskedastisitas.

\section{HASIL DAN PEMBAHASAN}

Pengujian hipotesis dalam penelitian ini mengunakan analisis regresi. Variabel independen dianggap berpengaruh signifikan apabila nilai signifikansinya kurang dari 0,05. Hasil pengujian hipotesis dapat dilihat pada tabel 4.10.

Berdasarkan tabel 4.10 variabel beta saham (BET) menunjukkan koefisien sebesar 0,425 dan nilai sig/2 adalah sebesar 0,000 (kurang dari 0,05 ). Hal ini berarti beta saham berpengaruh positif secara signifikan terhadap biaya modal ekuitas sehingga hipotesis pertama pada penelitian ini diterima. Variabel independen likuiditas saham (LIQ) menunjukkan hasil koefisien sebesar 0,013 dan nilai sig/2nya adalah sebesar 0,393. Hal ini berarti hipotesis kedua dalam penelitian ini ditolak, artinya likuiditas saham tidak berpengaruh terhadap biaya modal ekuitas.

Tabel 4.10

\section{Hasil Pengujian Hipotesis}

\begin{tabular}{|c|c|c|c|c|c|c|c|}
\hline \multirow{2}{*}{ MODEL } & \multirow{2}{*}{$\begin{array}{c}\text { Expected } \\
\text { sign }\end{array}$} & \multicolumn{2}{|c|}{$\begin{array}{c}\text { Unstandardized } \\
\text { Coefficients }\end{array}$} & \multirow{2}{*}{ T } & \multirow{2}{*}{ Sig. } & $\begin{array}{c}\text { Sig. } \\
(\boldsymbol{\alpha} / \mathbf{2})\end{array}$ & Hasil \\
\cline { 3 - 6 } & $\mathbf{B}$ & Std. Error & & & & \\
\hline (Constant) & & $-0,209$ & 0,036 & $-5,806$ & 0,000 & 0,000 & \\
\hline BET & + & 0,425 & 0,011 & 37,601 & 0,000 & 0,000 & Diterima \\
\hline LIQ & - & 0,013 & 0,047 & 0,273 & 0,785 & 0,393 & Ditolak \\
\hline UKP & - & 0,031 & 0,01 & 2,983 & 0,003 & 0,015 & Ditolak \\
\hline SPI & - & $-0,042$ & 0,011 & $-3,823$ & 0,000 & 0,000 & Diterima \\
\hline IDK & - & 0,054 & 0,028 & 1,942 & 0,053 & 0,027 & Ditolak \\
\hline KKA & - & 0,001 & 0,013 & 0,041 & 0,967 & 0,484 & Ditolak \\
\hline SIZ & - & 0,001 & 0,006 & 0,154 & 0,878 & 0,439 & Ditolak \\
\hline ROA & - & $-0,021$ & 0,012 & $-1,82$ & 0,069 & 0,035 & Diterima \\
\hline LEV & + & $-0,008$ & 0,008 & $-0,925$ & 0,355 & 0,178 & Ditolak \\
\hline
\end{tabular}

Sumber : Data sekunder yang diolah (2018) 
Sedangkan variabel ukuran KAP (UKP) menunjukkan hasil nilai koefisien regresi ukuran KAP yang berafiliasi Big 4 adalah sebesar 0,031 dengan nilai sig/2 sebesar 0,0015 (lebih dari 0,05). Hal ini berarti hipotesis kedua yang mengatakan bahwa ukuran KAP berpengaruh negatif terhadap biaya modal ekuitas ditolak. Selanjutnya variabel keempat dalam penelitian ini yaitu spesialisasi industri auditor (SPI) memiliki koefisien -0,042 dengan nilai signifikasi sebesar 0,000 dimana nilai ini lebih kecil dari 0,05 sehingga hipotesis keempat diterima.

Variabel independensi dewan komisaris (IDK) memiliki koefisien sebesar 0,054 dan nilai signifikansi sebesar 0,027 dimana nilai signifkansi tersebut lebih kecil dari 0,05. Hal tersebut menunjukkan bahwa hipotesis independensi dewan komisaris berpengaruh negatif terhadap biaya modal ekuitas ditolak. Kemudian hasil dari penelitian variabel keahlian komite audit (KKA) memiliki koefisien sebesar 0,001 dengan nilai signifikansi sebesar 0,484. Nilai signifikansi tersebut lebih besar dari 0,05 sehingga dapat disimpulkan bahwa keahlian komite audit tidak berpengaruh terhadap biaya modal ekuitas sehingga hipotesis keenam dalam penelitian ini ditolak.

Hasil untuk variabel kontrol menunjukkan variabel kontrol ukuran perusahaan (SIZ) memiliki nilai signifikansi ukuran perusahaan yaitu 0.439 lebih besar dari 0,05 . Hal ini menunjukan bahwa ukuran perusahaan tidak berpengaruh terhadap biaya modal ekuitas. Kemudian variabel kontrol profitabilitas (ROA) menunjukkann koefisien sebesar -0,021 dan nilai signifikansi sebesar 0,035 dimana lebih kecil dari 0,05 sehingga profitabilitas berpengaruh negatif terhadap biaya modal ekuitas. Sedangkan variabel kontrol leverage (LEV) memiliki hasil signifikansi 0,178 lebih besar dari 0,05 dan koefisien regresi leverage sebesar $-0,008$. Artinya bahwa leverage berpengaruh negatif namun tidak signifikan terhadap biaya modal ekuitas.

\section{PEMBAHASAN}

\section{Pengaruh Beta Saham Terhadap Biaya Modal Ekuitas}

Berdasarkan tabel 4.10 hasil penelitian variabel ini menunjukkan bahwa koefisien dari variabel beta saham (BET) adalah sebesar 0,425 dengan nilai signifikansi sebesar $0.000<$ 0,05 sehingga dapat disimpulkan bahwa hipotesis pertama dalam penelitian terdukung secara statistik.

Menurut Fahdiansah (2016) salah satu risiko perusahaan adalah pengungkapan informasi karena hal ini dapat menyebabkan terjadinya asimetri informasi atau ketimpangan informasi antara perusahaan dan investor. Asimetri yang semakin tinggi mencerminkan bahwa risiko perusahaan yang ditunjukkan oleh nilai beta saham juga akan semakin tinggi. Risiko yang semakin tinggi ini akan menyebabkan investor kurang percaya terhadap informasi yang ada pada laporan keuangan sehingga penilaian investor terhadap perusahaan tersebut juga akan semakin jauh dari nilai intrinsiknya. Penilaian investor yang demikian akan menyebabkan semakin besar selisih antara ekspektasi perusahaan terhadap penilaian investor sehingga biaya modal ekuitas yang ditanggung oleh perusahaan juga akan semakin besar.

Hal ini berarti apabila beta saham yang sering digunakan oleh para investor dalam pengambilan keputusan ketika berinvestasi dalam sebuah perusahaan semakin tinggi, maka biaya modal ekuitas yang harus ditanggung oleh perusahaan juga harus semakin tinggi (Dewi dkk, 2017). Hasil penelitian ini mendukung hasil penelitian Dewi et al. (2017), Yanesari et al. (2012), dan Fahdiansah (2016) yang meneliti mengenai pengaruh beta saham terhadap biaya 
modal ekuitas menunjukkan hasil bahwa beta saham berpengaruh positif terhadap biaya modal ekuitas.

\section{Pengaruh Likuiditas Saham Terhadap Biaya Modal Ekuitas}

Berdasarkan tabel 4.10 hasil uji hipotesis kedua ini menunjukkan nilai signifikansi sebesar 0,393 dimana nilainya lebih besar dari 0,05 sehingga hipotesis kedua dalam penelitian ini ditolak, artinya likuiditas saham tidak berpengaruh terhadap biaya modal ekuitas. Hal ini menunjukkan bahwa tidak ada beda antara perusahaan yang memiliki tingkat likuiditas tinggi maupun rendah dalam mempengaruhi besarnya biaya modal ekuitas yang harus ditanggung oleh perusahaan.

Menurut Ferdian (2012) likuiditas saham perusahaan yang ada di Indonesia dianggap investor sering mengalami perubahan atau fluktuasi akibat adanya kondisi perekonomian, politik, dan keamanan yang secara tidak langsung mempengaruhi likuiditas saham yang ada. Oleh karena itu, pengambilan keputusaan investor dalam menilai perusahaan sebelum berinvestasi dan ekpektasi investor terhadap return tidak dipengaruhi oleh likuiditas saham (Putra, 2015). Hal ini juga membuat perusahaan tidak perlu mengkhawatirkan pengaruh kondisi likuiditas saham perusahaan terhadap penilaian investor sehingga biaya modal ekuitas yang harus perusahaan tanggung juga tidak akan berubah. Hasil penelitian ini mendukung penelitian Putra (2015) dan Ferdian (2012) yang menemukan bahwa likuiditas saham tidak berpengaruh terhadap biaya modal ekuitas.

\section{Pengaruh Ukuran KAP Terhadap Biaya Modal Ekuitas}

Berdasarkan tabel 4.10 dari hasil uji regresi yang telah dilakukan, variabel ukuran KAP ini menunjukkan koefisien sebesar 0,031 dengan nilai sig/2 sebesar 0,0015 (lebih kecil dari $0,05)$. Hal ini berarti hipotesis ketiga pada penelitian ini yang mengatakan bahwa ukuran KAP berpengaruh negatif terhadap biaya modal ekuitas secara statistik ditolak.

Temuan tersebut investor menganggap hubungan kedekatan KAP Big 4 dengan klien akan dapat mengakibatkan tingginya tingkat risiko informasi dalam laporan keuangan perusahaan sehingga investor akan menilai perusahaan semakin jauh dari kondisi perusahaan yang sesungguhnya dan pada akhirnya biaya modal ekuitas yang harus ditanggung oleh perusahaan akan menjadi semakin besar (Hermawan, 2016). Hasil penelitian ini mendukung hasil penelitian Herusetya (2012) dan Hermawan (2016) yang menemukan bahwa ukuran KAP berpengaruh positif terhadap biaya modal ekuitas.

\section{Pengaruh Spesialisasi Industri Auditor Terhadap Biaya Modal Ekuitas}

Berdasarkan tabel 4.10 menunjukkan bahwa variabel spesialisasi industri auditor memiliki koefisien -0,042 dengan nilai signifikasi sebesar 0,000 dimana nilai ini lebih kecil dari 0,05 sehingga hipotesis keempat diterima. Hal ini berarti laporan keuangan perusahaan yang diaudit oleh auditor dengan spesialisasi industri terbukti dapat menekan biaya modal ekuitas yang harus ditanggung oleh perusahaan.

Laporan keuangan perusahaan diaudit oleh auditor yang memiliki spesialiasai industri auditor maka biaya modal ekuitas perusahaan akan dapat ditekan. Auditor dengan spesialisasi industri lebih banyak memiliki pengetahuan, pemahaman, dan pengalaman mengenai permasalahan serta istilah-istilah dalam industri tertentu. Selain itu, laporan keuangan yang diaudit oleh auditor dengan spesialisasi industri menunjukkan discretional accrual yang lebih rendah dan earning reponse coefficient (ERC) yang lebih tinggi daripadi klien tanpa auditor dengan spesialisasi industri. Hal ini akan mendorong investor semakin yakin untuk menilai 
perusahaan semakin mendekati nilai intrinsiknya dan pada akhirnya biaya modal ekuitas yang harus ditanggung perusahaan menjadi semakin kecil.

Hasil penelitian ini mendukung penelitian dari Fernando et al. (2010), Herusetya (2012), dan Khan et al. (2014) yang meneliti mengenai pengaruh spesialisasi industri auditor dan hasilnya menjelaskan bahwa spesialisasi industri auditor memiliki pengaruh negatif terhadap biaya modal ekuitas.

\section{Pengaruh Independensi Dewan Komisaris Terhadap Biaya Modal Ekuitas}

Berdasarkan tabel 4.10 hasil pengujian dalam penelitian ini menunjukan bahwa variabel independensi dewan komisaris memiliki koefisien sebesar 0,054 dan nilai signifikansi sebesar 0,027 dimana nilai signifkansi tersebut lebih kecil dari 0,05. Hal tersebut berarti hipotesis kelima yang mengatakan bahwa independensi dewan komisaris berpengaruh negatif terhadap biaya modal ekuitas secara statistik ditolak.

Menurut Hadiprajitno dan Rahardian (2014) adanya beberapa anggota dewan komisaris independen dalam sebuah perusahaan diduga hanya untuk formalitas saja. Sedangkan peranan penting dalam perusahaan tersebut masih diambil alih oleh pemegang saham mayoritas (blockholders) sehingga kinerja pengawasan dewan komisaris tidak efektif. Berdasarkan teori agensi, adanya hal yang demikian akan menimbulkan konflik kepentingan. Hal ini membuat penilaian investor menjadi semakin jauh dari apa yang diharapkan oleh perusahaan. Hal inilah yang menyebabkan biaya modal ekuitas perusahaan semakin tinggi. Hasil penelitian ini mendukung penelitian Zulfikar (2016) yang menemukan bahwa dewan komisaris independen berpengaruh positif terhadap biaya modal ekuitas.

\section{Pengaruh Keahlian Komite Audit Terhadap Biaya Modal Ekuitas}

Hasil penelitian variabel keahlian komite audit ini yang ditunjukkan pada tabel 4.10 memiliki koefisien sebesar 0,001 dengan nilai signifikansi sebesar 0,484. Nilai signifikansi tersebut lebih besar dari 0,05 . Hal ini berarti keahlian komite audit tidak berpengaruh terhadap biaya modal ekuitas sehingga hipotesis keenam dalam penelitian ini ditolak.

Hal ini mungkin dianggap oleh investor sebagai formalitas saja dari perusahaan karena sudah ada peraturan yang berasal dari Otoritas Jasa Keuangan (OJK) Nomor 55/Pojk.04/2015 yang mengatur tentang Pembentukan dan Pedoman Pelaksanaan Kerja Komite Audit. Peraturan tersebut mengharuskan salah satu anggota komite audit perusahaan harus memiliki latar belakang akuntansi atau keuangan (OJK, 2015). Hasil ini mendukung penelitian dari Sari (2009) serta Kurniawati dan Marfuah (2014).

\section{Variabel Kontrol}

Penelitian ini menggunakan tiga variabel kontrol yaitu ukuran perusahaan, profitabilitas, dan leverage. Nilai signifikansi ukuran perusahaan yaitu 0.439 lebih besar dari 0,05 . Hal ini menunjukan bahwa ukuran perusahaan tidak berpengaruh terhadap biaya modal ekuitas. Hasil penelitian ini konsisten dengan penelitian Susanti (2012) yang menemukan bahwa tidak ada pengaruh ukuran perusahaan terhadap biaya modal ekuitas.

Variabel kontrol yang kedua adalah profitabilitas yang diukur menggunakan ROA. Berdasarkan hasil penelitian ini, variabel ROA menunjukkann koefisien sebesar -0,038 dan nilai signifikansi sebesar 0,035 dimana lebih kecil dari 0,05 sehingga profitabilitas berpengaruh negatif terhadap biaya modal ekuitas. Hasil penelitian ini konsisten dengan hasil Yanesari et al. (2012), Purwaningtias dan Surifah (2015), Houqe et al. (2015) menunjukkan bahwa ROA berpengaruh negatif terhadap biaya modal ekuitas yang artinya ROA yang tinggi akan menurunkan biaya modal ekuitas suatu perusahaan. 
Selain itu, variabel kontrol yang ketiga adalah leverage. Nilai signifikansi leverage yaitu 0,178 lebih besar dari 0,05 dan koefisien regresi leverage sebesar -0,019. Artinya bahwa leverage berpengaruh negatif namun tidak signifikan terhadap cost of equity. Hasil penelitian ini menunjukan konsisten Ariyani dan Nugrahanti (2012).

\section{KESIMPULAN DAN SARAN}

\section{Kesimpulan}

Berdasarkan penelitian ini, maka didapatkan kesimpulan sebagai berikut:

1. Variabel beta saham memiliki pengaruh positif terhadap biaya modal ekuitas. Hipotesis pertama secara empiris diterima.

2. Likuiditas saham tidak berpengaruh terhadap biaya modal ekuitas. Secara empiris, hipotesis kedua dalam penelitian ini ditolak.

3. Variabel ukuran KAP berpengaruh positif terhadap biaya modal ekuitas. Hipotesis ketiga dalam penelitian ini ditolak.

4. Spesialiasai industri auditor berpengaruh negatif terhadap biaya modal ekuitas. Hipotesis keempat dalam penelitian ini diterima.

5. Independensi dewan komisaris berpengaruh positif terhadap biaya modal ekuitas. Secara empiris, hipotesis kelima dalam penelitian ini ditolak.

6. Keahlian komite audit tidak berpengaruh terhadap biaya modal ekuitas. Hipotesis keenam dalam penelitian ini secara empiris ditolak.

7. Variabel kontrol ukuran perusahaan tidak berpengaruh terhadap biaya modal ekuitas.

8. Variabel kontrol profitabilitas berpengaruh negatif terhadap biaya modal ekuitas.

9. Variabel kontrol leverage tidak berpengaruh terhadap biaya modal ekuitas.

\section{Saran Penelitian}

Berdasarkan penelitian ini didapatkan saran untuk penelitian selanjutnya, yaitu:

1. Penelitian ini telah memberikan bukti empiris mengenai faktor-faktor yang mempengaruhi biaya modal ekuitas. Namun proksi pengukuran tata kelola perusahaan dalam penelitian ini hanya independensi dewan komisaris dan keahlian komite audit. Penelitian selanjutnya dapat menambah pengukuran lainnya seperti dewan direksi, kepemilikan managerial (Chairunnisa (2014)), kepemilikan institusional (Rebecca dan Siregar (2013)).

2. Pengukuran variabel dependen biaya modal ekuitas menggunakan capital asset pricing model (CAPM). Penelitian berikutnya dapat digunakan pengukuran seperti pertumbuhan nilai constant dan model ohlson seperti penelitian Utami (2005) dan Khikmah, et al. (2015) sehingga kesimpulan dapat lebih menyakinkan pengguna informasi. 


\section{DAFTAR PUSTAKA}

Akbar, F .N. 2014. Efektivitas Komite Audit Terhadap Ketepatan Waktu Pelaporan Keuangan (Studi Empiris pada Perusahaan Publik yang terindikasi Kesulitan Keuangan Tahun 2010-2012). Skripsi. Universitas Diponegoro, Semarang, Indonesia.

Analisa, Y. 2011. Pengaruh Ukuran Perusahaan, Kebijakan Dividen terhadap Nilai Perusahaan. Skripsi. Universitas Diponegoro, Semarang, Indonesia..

Anastasia, Y. 2016. Pengaruh Pengungkapan Sukarela, Beta Saham dan Ukuran Perusahaan terhadap Cost of Equity Capital pada Perusahaan Barang Konsumsi di Indonesia. Skripsi. Universitas Lampung, Bandar Lampung, Indonesia .

Ariyani, M., dan Y. W. Nugrahanti. 2012. Pengaruh Pengungkapan Corporate Social Responbility terhadap Cost Of Equity Perusahaan. Skripsi. Universitas Kristen Satya Wacana, Salatiga, Indonesia.

Ashidiqi, M. L. 2013. Pengaruh Manajemen Laba, Risiko Beta, dan Ukuran Perusahaan terhadap Biaya Modal Ekuitas Perusahaan Manufaktur yang Terdaftar di Bursa Efek Indonesia Periode 2009-2011. Skripsi. Universitas Negeri Yogyakarta, Yogyakarta, Indonesia.

Butar Butar, S. 2007. Modul Statistik dan Aplikasi SPSS. Semarang: Fakultas Ekonomi Unika Soegijapranata.

Butar Butar, S. 2014. Reputasi Auditor, Karakteristik Dewan Komisaris, Dan Keinformatifan Laba. Jurnal Akuntansi Bisnis 13 (2): 25-43.

Chairunnisa, D. 2014. Pengaruh Good Corporate Governance dan Asimetri Informasi terhadap Cost of Equity Capital Equity Capital. Skripsi. Universitas Jember, Jember, Indonesia.

Desiliani. 2014. Pengaruh Ukuran Kantor Akuntan Publik, Spesialisasi Industri Auditor dan Audit Tenure Pada Biaya Modal. Skripsi. Universitas Diponegoro, Semarang, Indonesia.

Desiliani, N, dan W. Meiranto. 2015. Spesialisasi Industri Auditor dan Audit Tenure pada Biaya Modal Ekuitas (Studi Empiris pada Perusahaan yang Terdaftar di Bursa Efek Indonesia Tahun 2010 - 2012). Diponegoro Journal of Accounting 4(1): 1-8.

Dewi, L., M. Wahyuni., dan E. Sujana. 2017. Manajemen Laba dan Beta Saham terhadap Cost of Equity Capital (Studi Empiris pada Perusahaan Perbankan yang Terdaftar Di BEI). e-Journal Universitas Pendidikan Ganesha 7(1).

Efrina, M., dan Faisal. 2017. Pengaruh Kualitas Laba dan Likuiditas Saham terhadap Biaya Modal Ekuitas pada Perusahaan. Jurnal Ilmiah Mahasiswa Ekonomi Manajemen 1(2): 134-53.

Eliza. 2013. Hubungan Nilai Intrinsik Suatu Saham Terhadap Harga Pasar Saham tersebut. Skripsi. Sekolah Tinggi Perpajakan Indonesia (STPI), Jakarta, Indonesia.

Fahdiansyah, R. 2016. The Influence of Voluntary Disclosure, Asymmetri Information, Stock Risk, Firm Size and Institutional Ownership towards Cost of Capital (COC). Jurnal Aplikasi Manajemen (66): 387-97. 
Fard, S. F. H. 2017. The Relationship between Information Asymmetry and Stock Liquidity and Cost of Equity Capital of Companies Listed on the Tehran Stock Exchange. Palma Journal (16): 34-39.

Ferdian, R. 2012. Pengaruh Likuiditas Saham dan Return On Equity (ROE) Perusahaan terhadap Tingkat Pengembalian Saham (Studi Pada Perusahaan yang berada pada Index LQ45 di Bursa Efek Indonesia (BEI) Periode 2009-2011). Skripsi. Universitas Widyatama, Bandung, Indonesia.

Fernando, G. D., A. M. Meguid., dan R. J. Elder. 2010. Audit Quality Attributes, Client Size and Cost of Equity Capital. Review of Accounting and Finance 9(4): 363-81.

Fiatmoko, A. L. 2015. Pengaruh Ukuran Perusahaan, Ukuran KAP, Laba/Rugi Operasi dan Opini Audit terhadap Audit Delay pada Perusahaan Perbankan yang terdaftar di BEI Tahun 2010-2012. Skripsi. Universitas Negeri Semarang, Semarang, Indonesia.

Ghozali, Imam. 2006. Analisis Multivariate dengan Program SPSS. Semarang : Badan Penerbit Universitas Diponegoro.

Handayani, A. 2017. Analisis Pengaruh Kepemilikan Keluarga, Diversitas Dewan Komisaris, Manajemen Laba, Kualitas Laba, Komisaris Independen, Kepemilikan Institusional dan Reputasi Auditor terhadap Nilai Perusahaan. Skripsi. Universitas Katolik Soegijapranata, Semarang, Indonesia.

Hermawan, M. 2016. The Influence of Audit Quality on Cost of Equity Capital : Evidence From Indonesia. Skripsi. Binus University International, Jakarta, Indonesia.

Herusetya, A. 2012. Dapatkah Kualitas Audit Mengurangi Biaya Modal Ekuitas Ex Ante?. Skripsi. Universitas Pelita Harapan, Jakarta, Indonesia.

Houqe, N., K. Ahmed., dan T. Zijl. 2015. Quality and Cost of Equity Capital : Evidence from India. Working Paper, Victoria University of Wellington, Wellington, New Zealand.

Hutapea, H. D. 2010. Pengaruh Beta Saham dan Return Saham terhadap Biaya Modal Ekuitas (Studi pada Perusahaan Manufaktur yang Terdaftar di Bursa Efek Indonesia). Skripsi. Universitas HKBP Nommensen, Medan, Indonesia

Imran, A. 2012. Pengaruh Ukuran Perusahaan, Pengungkapan Sukarela dan Manajemen Laba terhadap Cost of Equity Capital (Studi Empiris Pada Perusahaan Food and Beverages Yang Terdaftar Di Bursa Efek Indonesia). Skripsi. Politeknik Negeri Lhokseumawe, Nanggroe Aceh Darusssalam, Indonesia.

Jogiyanto. 2013. Metodologi Penelitian Bisnis : Salah Kaprah dan PengalamanPengalaman. Yogyakarta : BPFE.

Joni., dan Lina. 2010. Faktor-Faktor yang Mempengaruhi Struktur Modal. Jurnal Bisnis dan Akuntansi 12 (2): 81-96.

Khanmohammadi, M. H., dan A. A. Arbabian. 2014. The Relationship between Auditor's Attributes and Cost of Capital in Iran Capital Market. Academic Journal of Accounting and Economics Researches 3 (2): 204-15.

Khemakhem, H., dan A. Naciri. 2015. Do Board and Audit Committee Characteristics Affect Firm's Cost of Equity Capital? Journal of Business and Management 4 (2): 1-18.

Kirana, P. 2013. Pengaruh Kualitas Audit terhadap Cost of Equity Capital (Studi Empiris pada Perusahaan yang Terdaftar di Bursa Efek Indonesia Tahun 2011). Skripsi. Universitas Diponegoro, Semarang, Indonesia. 
Kurniawati, Z., dan Marfuah. 2014. Pengaruh Penerapan Corporate Governance terhadap Biaya Ekuitas dan Biaya Utang pada Perusahaan Manufaktur di Indonesia. Jurnal Bisnis dan Ekonomi 2 (5): 195-206.

Muhammad, R. 2014. Pengaruh Kualitas Audit, Kondisi Keuangan Perusahaan, Opini Audit Tahun Sebelumnya, Pertumbuhan Perusahaan terhadap Opini Audit Going Concern pada Perusahaan Manufaktur yang Terdaftar di Bursa Efek Indonesia. Skripsi. Universitas Sumatera Utara, Medan, Indonesia.

Mukminin, L. S. 2010. Pengaruh Audit Operasional terhadap Kinerja Non Keuangan dengan Audit atas Persediaan sebagai Variabel Intervening. Skripsi. Universitas Islam Negeri Syarif Hidayatullah, Jakarta, Indonesia.

Murniati, MP., Vena, P., SD.Ayu., Agnes, A., Yusni,W., Ranto, S. 2013. Alat-Alat Pengujian Hipotesis. Semarang: Unika Soegijapranata Semarang.

Komite Nasional Kebijakan Governance. (2002). "Pedoman Pembentukan Komite Audit Yang Efektif". Jakarta. Divisi Penerbitan KNKG.

Nasution, B. A. 2009. Pengaruh Struktur Modal, Biaya Ekuitas (Cost of Equity) dan Pertumbuhan Perusahaan terhadap Nilai Perusahaan dengan Klasifikasi Perusahaan Moderating pada Perusahaan Lembaga Keuangan yang terdaftar di BEI. Skripsi. Universitas Sumatera Utara, Medan, Indonesia.

Ningsih, R. D., dan N. E. Ariani. 2016. Pengaruh Asimetri Informasi, Pengungkapan Modal Intelektual, dan Kualitas Audit terhadap Biaya Modal Ekuitas (Studi pada Perusahaan LQ 45 yang terdaftar di Bursa Efek Indonesia Tahun 2012-2014). Jurnal Ilmiah Mahasiswa Ekonomi Manajemen 1(1) : 149 - 157.

Novade, D. 2015. Pengaruh Efektivitas Komite Audit terhadap Ketepatan Waktu Penyampaian Laporan Keuangan (Studi Empiris pada Perusahaan Non Keuangan yang terdaftar di Bursa Efek Indonesia Tahun 2013). Skripsi. Universitas Diponegoro, Semarang, Indonesia.

Nurfadilla, S. A. 2016. Analisis Pengaruh Dewan Komisaris Independen, Gender Diversity, Kepemilikan Institusional dan Kepemilikan Manajerial terhadap Kinerja Perusahaan (Studi Kasus pada Perusahaan yang terdaftar di Indonesia Sharia Stock Index Periode 2012 - 2014). Skripsi. Universitas Diponegoro, Semarang, Indonesia.

Nurjanah, Y., dan S. I Rosita. 2008. Pengaruh Beta Saham Terhadap Tingkat Imbal Hasil Saham Studi Kasus pada Perusahaan yang Listing di Bursa Efek Indonesia. Jurnal Ilmiah Kesatuan 10(2) : 81- 86.

Otoritas Jasa Keuangan. (2015). "Pembentukan dan Pedoman Pelaksanaan Kerja Komite Audit". Jakarta : Divisi Penerbitan OJK.

Oktarina, A. 2014. Pengaruh Akuntabilitas dan Pengalaman Kerja terhadap Pemberian Pendapat Auditor pada Kantor Akuntan Publik Di Palembang. Skripsi. Politeknik Negeri Sriwijaya, Palembang, Indonesia.

Palmrose, Z. 1988. Analysis of auditor litigation and audit service quality. The Accounting Review 63: 55-73.

Prastiti, A., dan W. Meiranto. 2013. Pengaruh Karakteristik Dewan Komisaris dan Komite Audit terhadap Manajemen Laba. Diponegoro Journal of Accounting 2 (4): 1-12. 
Pujiningsih, A. I. 2011. Pengaruh Struktur Kepemilikan Ukuran Perusahaan, Praktik Corporate Governance dan Kompensasi Bonus terhadap Manajemen Laba. Skripsi. Universitas Diponegoro, Semarang, Indonesia.

Purwaningtias, M. H., dan Surifah. 2015. Pengaruh Manajemen Laba Akrual terhadap Biaya Modal Ekuitas Ekuitas pada Perusahaan Manufaktur yang Terdaftar di Bursa Efek Indonesia Tahun 2011-2013. Seminar Nasional. Purwokerto, 26 September 2015.

Puteri, P .A. 2012. Analisis Pengaruh Investment Opportunity Set (IOS) dan Mekanisme Corporate Governance terhadap Kualitas Laba dan Nilai Perusahaan. Skripsi. Universitas Diponegoro, Semarang, Indonesia.

Putra, H. B. D. 2016. Analisis Pengaruh Manajemen Laba Riil, Ukuran Perusahaan dan Likuiditas Saham terhadap Cost of Equity Capital pada Perusahaan Go Public yang Tergabung dalam Indeks LQ45 dan JII. Skripsi. Universitas Muhammadiyah Surakarta, Surakarta, Indonesia.

Putri, B. W. 2012. Penentuan Kualitas Audit Berdasarkan Ukuran Kantor Akuntan Publik dan Biaya Audit. Jurnal Ilmiah Mahasiswa Akuntansi 1(4) : 60 -64.

Putri, E. 2013. Pengaruh Luas Pengungkapan Sukarela terhadap Biaya Modal dengan Asimetri Informasi sebagai Variabel Intervening (Studi Empiris pada Perusahaan Manufaktur yang terdaftar di BEI). Skripsi. Universitas Negeri Padang, Padang, Indonesia.

Qoriah, Y. 2014. Pengaruh Likuiditas Saham dan Return On Equity (ROE) terhadap Return Saham (Studi Kasus pada Perusahaan Indeks LQ45 Periode 2011-2014 di Bursa Efek Indonesia). Skripsi. Universitas Komputer Indonesia, Bandung, Indonesia.

Rahadian, A., P. B. Hadiprajitno., dan Soedharto. 2014. Pengaruh Good Corporate Governance terhadap Struktur Modal Perusahaan (Studi Empiris pada Perusahaan Manufaktur yang terdaftar di Bursa Efek Indonesia pada Tahun 2010-2012). Diponegoro Journal of Accounting 3 (2) : 1-12.

Riniati, K. 2015. Pengaruh Komisaris Independen dan Komite Audit terhadap Kinerja Perusahaan (Perusahaan yang Terdaftar di BEI 2011- 2013). Skripsi. Universitas Negeri Yogyakarta, Yogyakarta, Indonesia.

Rosita, S. 2016. Pengaruh Good Corporate Governance dan Manajemen Laba terhadap Biaya Ekuitas (Studi pada Perusahaan yang Terdaftar di Jakarta Islamic Index Tahun 20112015). Skripsi. Universitas Islam Negeri Sunan Kalijaga, Yogyakarta, Indonesia.

Sanjaya, F. B. 2017. Pengaruh Auditor Spesialisasi Industri, Ukuran KAP, Audit Tenure, Kepemilikan Keluarga, dan Kualitas Laba terhadap Cost of Equity. Skripsi. Universitas Soegijapranata, Semarang, Indonesia.

Sari, I. C., dan V. Diyanty. 2014. Pengaruh Efektifitas Dewan Komisaris dan Pengendali Keluarga terhadap Biaya Ekuitas. Skripsi. Universitas Indonesia, Jakarta, Indonesia.

Sari, P. A. 2009. Pengaruh Corporate Governance Mechanisms terhadap Cost of Equity Capital. Skripsi. Universitas Sebelas Maret, Surakarta, Indonesia.

Setiawan, J. A. 2013. Pengaruh Kualitas Audit terhadap Manajemen Laba dan Biaya Modal. Skripsi. Universitas Diponegoro, Semarang, Indonesia. 
Suparno, D. P., dan E. Kiswara. 2013. Analisis Hubungan antara Atribut Kualitas Audit dengan Biaya Ekuitas Modal (Studi Empiris pada Perusahaan yang Terdaftar di Bursa Efek Indonesia Tahun 2009-2011). Diponegoro Journal of Accounting 2 (3) : 1-7.

Susanti. 2012. Pengaruh Manajemen Laba terhadap Biaya Modal Ekuitas dengan Size sebagai Variabel Kontrol pada Perusahaan Manufaktur yang terdaftar di Bursa Efek Indonesia Tahun 2007-2009. Skripsi. Universitas Kristen Satya Wacana, Salatiga, Indonesia.

Tarjo. 2010a. Mekanisme Tata Kelola Korporat: Mampukah Menurunkan Cost of Equity Capital? Jurnal Akuntansi 6(1): 47-59.

- 2010b. Pengaruh Struktur Kepemilikan dalam Mekanisme Corporate Governance Terhadap Cost of Equity Capital. Jurnal Investasi 1(1): 89-104.

Wardani, F. 2015. Pengaruh Efektivitas Komite Audit, Ukuran Perusahaan dan Leverage terhadap Kualitas Laporan Keuangan. Skripsi. UIN Syarif Hidayatullah, Jakarta, Indonesia.

Winarto, Y. 2010. Analisis Perbedaan Pengaruh Manajemen Laba dan Mekanisme Good Corporate Governance terhadap Biaya Modal Ekuitas pada Perusahaan di BEI sebagai Peserta dan Non Peserta Corporate Governance Perception Index (CGPI). Skripsi. Unika Soegijapranata, Semarang, Indonesia.

Wulansari, F. 2012. Pengaruh Ukuran KAP dan Opini Audit terhadap Audit Delay (Studi Kasus pada Kantor Akuntan Publik di Wilayah Bandung). Skripsi. Universitas Komputer Indonesia, Bandung, Indonesia.

Yanesari, A. M. 2012. Audit Quality and Corporate Cost of Capital: An Iranian Perspective. Archives Den Sciences. 65(8): 17-27.

Zulfikar, A. A. A. 2016. Pengaruh Pengungkapan Corporate Social Responsibility dan Mekanisme Corporate Governance terhadap Cost of Equity Perusahaan pada Perusahaan yang terdaftar Di Jakarta Islamic Index Periode 2011-2014. Skripsi. Universitas Islam Negeri Sunan Kalijaga, Yogyakarta, Indonesia. 